\title{
Feasibility analysis of using mine water from abandoned coal mines in Spain for heating and cooling of buildings
}

\author{
Javier Menéndez ${ }^{\mathrm{a},{ }^{*}}$, Almudena Ordónez ${ }^{\mathrm{b}}$, Jesús M. Fernández-Oro ${ }^{\mathrm{c}}$, Jorge Loredo ${ }^{\mathrm{b}}$, \\ María B. Díaz-Aguado ${ }^{\mathrm{b}}$ \\ ${ }^{a}$ Hunaser Energy, Avda. Galicia, 44, 33005, Oviedo, Spain \\ ${ }^{\mathrm{b}}$ Dep. Mining Exploitation and Prospecting, University of Oviedo, Independencia 13, 33004, Oviedo, Spain

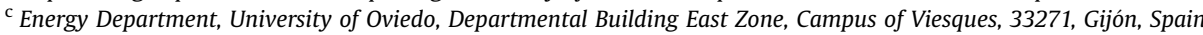

\section{A R T I C L E I N F O}

\section{Article history:}

Received 30 April 2019

Received in revised form

5 July 2019

Accepted 9 July 2019

Available online 10 July 2019

\section{Keywords:}

Abandoned mines

Mine water

Geothermal energy

Heat pump

Underground mining reservoir

Sustainable energy

\begin{abstract}
A B S T R A C T
In 2017, renewable energy accounted for $19.5 \%$ of the total energy used for heating and cooling in the European Union. This paper analyses the technical and economic feasibility of using mine water from flooded underground coal mines in Spain to provide renewable thermal energy to buildings located in surrounding areas. High efficiency heat pump system is proposed to provide sustainable energy for district heating and cooling, leading to a reduction of greenhouse gas emissions to the atmosphere. The results obtained show that $20 \mathrm{MW}$ of thermal energy is available for heat recovery from mine waters, compared to $4 \mathrm{MW}$ of electrical power committed for pumping from inside the mines and heat pump consumption. The economic model that has been developed indicates that the feasibility of the geothermal plants depends on the amount of thermal energy demanded, the efficiency of the system and the distance from the abandoned mines to potential users. A mine water geothermal plant with $10 \mathrm{MW}$ of power provides energy for about 1,700 households at a distance of $2 \mathrm{~km}$ with an investment cost of $3.25 \mathrm{M} €$. Regarding the reduction of $\mathrm{CO}_{2}$ emissions, the emission factor is reduced to $0.048 \mathrm{kgCO}_{2} \mathrm{kWh}^{-1}$ using this approach.
\end{abstract}

() 2019 Elsevier Ltd. All rights reserved.

\section{Introduction}

The use of renewable energy sources (RES) for energy generation has increased considerably in recent years. Due to the reduction of greenhouse gas (GHG) emissions, in the coming years it is expected that the RES will replace a significant percentage of fossil fuels such as coal and natural gas in the generation of electrical and thermal energy. In 2017, renewable energy accounted for $19.5 \%$ of the total energy used for heating and cooling in the European Union (EU) [1]. The majority of the coal mines in EU were closed down at the end of the 20th century due to economic, environment and political reasons [2-4]. Moreover, the European Decision 2010/787/ EU establishes that the operation of the coal production units concerned must form part of a closure plan with a deadline that cannot be extended beyond 31 December 2018.

Since mining induces fractures in the rock mass, the infiltration of rainwater from the recharge area is enabled, so an intense

\footnotetext{
* Corresponding author.

E-mail address: jmenendezr@hunaser-energia.es (J. Menéndez).
}

pumping had to be maintained when the mine was active [5]. This pumping is typically stopped when the mining operation ceases, leading to the gradual flooding of the mine voids or the so-called groundwater rebound [6]. Many times in the process of flooding the mine, when the water level reaches the surface, environment damage occurs in the vicinity of the abandoned mines [7]. In order to prevent possible uncontrolled discharges of mine water, dewatering must continue even after the mines closure to keep the uppermost workings dry and avoid flooding in the basements of the buildings located near the closed mines. Submersible pumps are typically installed in closed coal mines to maintain mine water level at $60-100 \mathrm{~m}$ below ground level. This supposes an eternal groundwater pumping, with important economic consequences.

In addition, after decades of mining activity, the created mine voids and the effect of the induced fracturing on the enclosing rocks have modified the initial permeability which induces important changes into the hydrogeological properties of the area. It has been observed that the values of porosity, permeability and transmissivity may be increased significantly from their initial values: porosity from 1 to more than $10 \%$, permeability from $10^{-1}-100 \mathrm{~m}$ 
day $^{-1}$, and transmissivity from 10 to $1,000 \mathrm{~m}^{2}$ day $^{-1}$ [8]. Also, the studies carried out indicate that after closure the quality of the stored water deteriorates significantly [9-11]. Conversely, the quality of the mine water improves after $3-5$ years $[12,13]$.

To compensate for the eternal pumping costs, a low-carbon alternative may be the heat recovery from stored mine water in conjunction with heat pumps. Several theoretical studies have been carried out to analyze the geothermal potential in flooded coal mines [14-17]. The mine water from abandoned coal mines can also be used for the development of Underground Pumped Storage Power (UPSH) or Compressed Air Energy Storage (CAES) plants [18-22]. Large amounts of stored water at stable temperature and low enthalpy are suitable for the supply of sustainable thermal energy in surrounding buildings. Due to the relatively low temperature of the mine water, heat pumps are necessary to increase the temperature for conventional heating systems. Although the use of mine water in closed and flooded underground mines has important economic and environment benefits, there is a small number of geothermal plants under operation in coal mines [23].

The aim of the present investigation is to make an assessment of the technical and economic feasibility of using geothermal energy available in three closed and flooded coal mines in NW Spain. Heat recovery schemes by means of high efficiency heat pumps are proposed to provide space heating and cooling of buildings. Geochemical properties of mine water, temperature gradient in the mining reservoir and annual water volume available have been analyzed. An economic model has been developed in order to estimate the profitability of the investment based on the efficiency of the system and the distance from flooded coal mines to potential users. Finally, savings of $\mathrm{CO}_{2}$ compared to conventional fossil fuels have been estimated.

\section{Mine water heat recovery plants under operation}

There are several geothermal installations worldwide that recover energy from mine water available in abandoned coal mines. The mine water is passed through heat pumps and the thermal energy produced in the condenser is used for heating and cooling of buildings. Table 1 shows the summary of some geothermal plants with mine water under operation.

In Nova Scotia, Canada, a geothermal energy plant was implemented in 1990 at the flooded closed Ropak Can Am coal mine in Springhill [24,25]. An open loop system design, with 11 heat pumps, condition $16,700 \mathrm{~m}^{2}$ of buildings. Each heat pump has a motor rated at $3.73 \mathrm{~kW}$ and provides space heating and cooling taking water from the closed mine at a depth of $140 \mathrm{~m}$ and at temperature of $18^{\circ} \mathrm{C}$. The estimated COP for the system is 3.5.

An open loop system with drilled boreholes $700 \mathrm{~m}$ deep into flooded coal mine workings is used in the Netherlands to provide space heating and cooling for 350 dwellings, $3,800 \mathrm{~m}^{2}$ of commercial areas and $16,200 \mathrm{~m}^{2}$ of community buildings [26]. The Heerlen project has four heat pumps with a capacity of $700 \mathrm{~kW}$. The temperature of the mine water is $30-35^{\circ} \mathrm{C}$ in the winter and

Table 1

Summary of geothermal plants with mine water under operation.

\begin{tabular}{lccc}
\hline Mine site & Power $(\mathrm{kW})$ & Mine water temperature & COP \\
\hline Nova Scotia (Canada) & 3.73 & $18^{\circ} \mathrm{C}$ & 3.5 \\
Heerlen (Netherlands) & 700 & $30-35^{\circ} \mathrm{C}$ & 5.6 \\
Marienberg (Germany) & 690 & $12^{\circ} \mathrm{C}$ & N/A \\
Freiberg (Germany) & N/A & $10.2^{\circ} \mathrm{C}$ & 3.5 \\
Park Hills (Missouri, USA) & 112 & $14{ }^{\circ} \mathrm{C}$ & N/A \\
Hope Shaft (UK) & 10 & $14{ }^{\circ} \mathrm{C}$ & 3.95 \\
Barredo Shaft (Asturias, Spain) & 3,500 & $23^{\circ} \mathrm{C}$ & 5.5 \\
\hline
\end{tabular}

$16-19^{\circ} \mathrm{C}$ in the summer. Due to the high temperatures in the winter, a COP of 5.6 is reached. In Marienberg, Germany, a geothermal plant was installed in an uranium exploitation using mine water at a temperature of $12^{\circ} \mathrm{C}$ and a capacity of over $120 \mathrm{~m}^{3} \mathrm{~h}^{-1}$ [27]. The system provides a heat capacity of $690 \mathrm{~kW}$ with a closed loop configuration. Also in Germany, in Freiberg, mine water from an abandoned mining drift is used to supply space heating and cooling to a castle [28]. The system provides water at $10.2{ }^{\circ} \mathrm{C}$ and $3 \mathrm{~L} \mathrm{~s}^{-1}$ to a heat pump. The system has an overall COP of 3.5 .

Another example of a geothermal plant was implemented in the municipal building in Park Hills, Missouri, USA [29]. An open loop system with submersible pump supplies mine water from a closed flooded lead mine to 9 heat pumps. With a capacity of $112 \mathrm{~kW}$, the system is able to provide space heating to $750 \mathrm{~m}^{2}$ of buildings. Similarly, in the UK, the Hope shaft is currently pumped on a daily basis by a submersible pump to maintain mine water levels at 148-153 m below ground level. A $10 \mathrm{~kW}$ heat pump was installed at Hope in April 2015 to provide space heating to a small building housing a museum exhibition [30]. Water is pumped at around $76 \mathrm{~L} \mathrm{~s}^{-1}$ for $12-16 \mathrm{~h} \mathrm{day}^{-1}$, typically from 10 to 11 p.m. onwards, to take advantage of cheaper night-time electricity.

In Northwest Spain (Asturias), there are currently some projects under operation using mine water from flooded coal mines at an average temperature of $23^{\circ} \mathrm{C}$. In 2012, an open loop geothermal plant was installed to provide space heating and cooling to a Hospital that is located at a distance of $2 \mathrm{~km}$ from the coal mine. The mine water goes directly to heat exchanger placed on the mine installations. It is a tubular heat exchanger with a thermal exchanging power of $3,500 \mathrm{~kW}$ [30]. After the exchange, the mine water is discharged into a river. The heat is given to a secondary circuit that is a secondary close loop of clean water of $4 \mathrm{~km}$ made with polyethylene pipes, $\varnothing 400 \mathrm{~mm}$. Three pumps $(3 \times 55 \mathrm{~kW})$ are used to circulate this clean water to the heat pumps in the hospital. Hospital thermal installation includes two additional heat pumps, which can provide heating $(1,509 \mathrm{~kW}$ each one) or cooling (1,141 kW each one) to the building, depending on the climate conditions and the specific needs of the clima system. Another chiller produce simultaneous heating and cooling in a compensated generation system.

\section{Methodology}

\subsection{Study area}

The study area is located in the Asturian Central Coal Basin (ACCB), in NW Spain, which has an extension of about $1,400 \mathrm{~km}^{2}$. Fig. 1 shows the location of the study area and three closed mines in NW Spain. The ACCB has been a highly exploited coal mining area for many years and its network of tunnels covers more than 30 mines. The typical structure of underground coal mines consists of a main vertical shaft for access and extraction of coal, and networks of horizontal drifts at different levels. There are also auxiliary shafts for the ventilation system and as emergency exits. The depth of the mining operations reached $600 \mathrm{~m}$ below ground level. Coal mines in the ACCB have been closed at the end of 2018. There is only one mine under operation to supply fuel to a power plant that still uses as fuel a mixture of coal and sterile from coal dumps.

The geothermal capacity of the water in the mines depends on volume and temperature. The amount of energy produced will depend on the size and number of heat pumps that are installed [31]. Mine water in the three mines under study has a direct pumped discharge, without further treatment system. Table 2 shows the annual volume of mine water available, temperature and geochemical data for the mine water existing in the three 


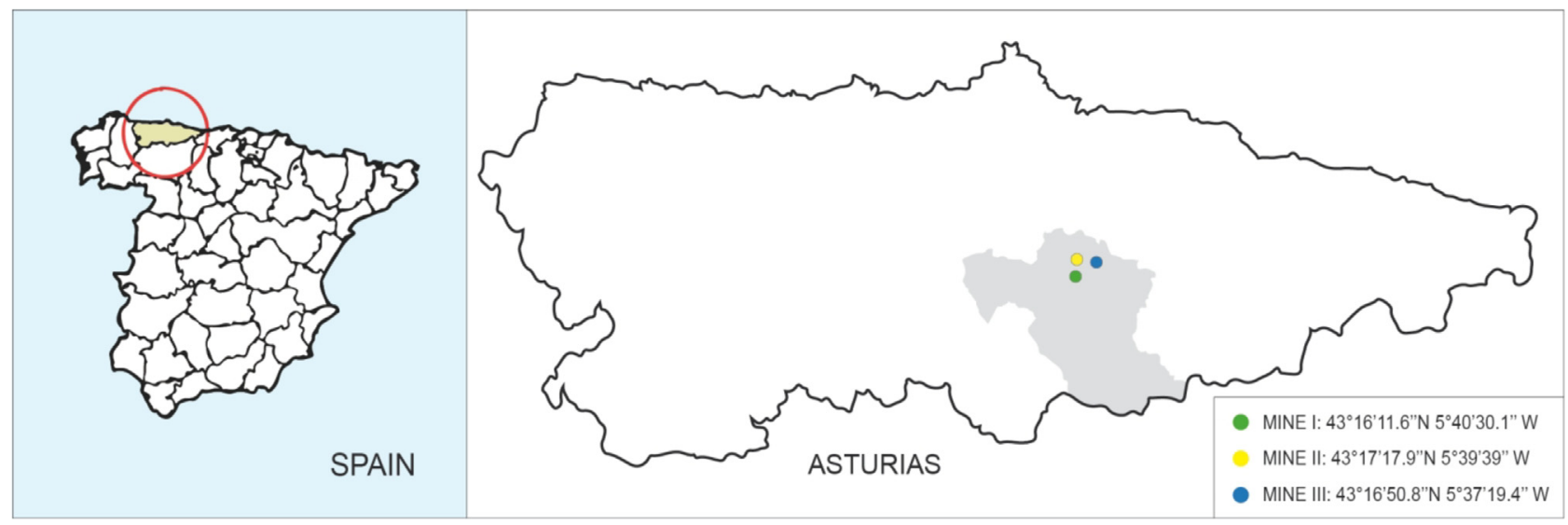

Fig. 1. Location of the study area and three coal mines in NW Spain.

Table 2

Physicochemical data of mine water in the three coal mines located in the ACCB.

\begin{tabular}{|c|c|c|c|}
\hline Location & Mine I & Mine II & Mine III \\
\hline Dewatering $\left(\mathrm{m}^{3}\right.$ year $\left.^{-1}\right)$ & $1.21 \times 10^{6}$ & $2.92 \times 10^{6}$ & $2.89 \times 10^{6}$ \\
\hline Date & $07 / 01 / 2018$ & $07 / 01 / 2018$ & $07 / 01 / 2018$ \\
\hline Temperature $\left({ }^{\circ} \mathrm{C}\right)$ & 23.0 & 20.6 & 21.2 \\
\hline $\mathrm{pH}$ & 7.71 & 7.74 & 7.76 \\
\hline Suspended Solids ( $\mathrm{mg} \mathrm{L}^{-1}$ ) & $<5.0$ & $<5.0$ & $<5.0$ \\
\hline Electrical Conductivity $\left(\mu \mathrm{S} \mathrm{cm}^{-1}\right)$ & 1.265 & 1.046 & 1.211 \\
\hline Alkalinity $\left(\mathrm{mg} \mathrm{L}^{-1}\right.$ as $\left.\mathrm{CaCO}_{3}\right)$ & 5 & 4 & 3 \\
\hline Dissolved Iron $\left(\mathrm{mg} \mathrm{L}^{-1}\right)$ & $<0.050$ & $<0.050$ & $<0.050$ \\
\hline Total Iron $\left(\mathrm{mg} \mathrm{L}^{-1}\right)$ & 0.270 & 0.198 & 0.174 \\
\hline Sulfates $\left(\mathrm{mg} \mathrm{L}^{-1}\right)$ & 140 & 130 & 70 \\
\hline Carbonates $\left(\mathrm{mg} \mathrm{L}^{-1}\right)$ & $<2.0$ & $<2.0$ & $<2.0$ \\
\hline Bicarbonates $\left(\mathrm{mg} \mathrm{L}^{-1}\right)$ & 725.3 & 492.0 & 558.9 \\
\hline Dissolved Calcium $\left(\mathrm{mg} \mathrm{L}^{-1}\right)$ & 116 & 88.8 & 54.2 \\
\hline Dissolved Magnesium $\left(\mathrm{mg} \mathrm{L}^{-1}\right)$ & 46 & 37 & 32.9 \\
\hline Dissolved Manganese $\left(\mathrm{mg} \mathrm{L}^{-1}\right)$ & $<0.008$ & $<0.008$ & $<0.008$ \\
\hline Dissolved Potassium $\left(\mathrm{mg} \mathrm{L}^{-1}\right)$ & 11.2 & 6.9 & 8.92 \\
\hline Dissolved Sodium $\left(\mathrm{mg} \mathrm{L}^{-1}\right)$ & 173 & 105 & 160 \\
\hline
\end{tabular}

closed coal mines that were considered for this investigation. Hunosa mining company provided the data of the mine water analysis.

A comparison between air and mine water temperatures is shown in Fig. 2. Mine waters in abandoned coal mines shown less seasonal variations than the air temperatures, due to thermal damping of geological formations [32]. Particularly, mine water

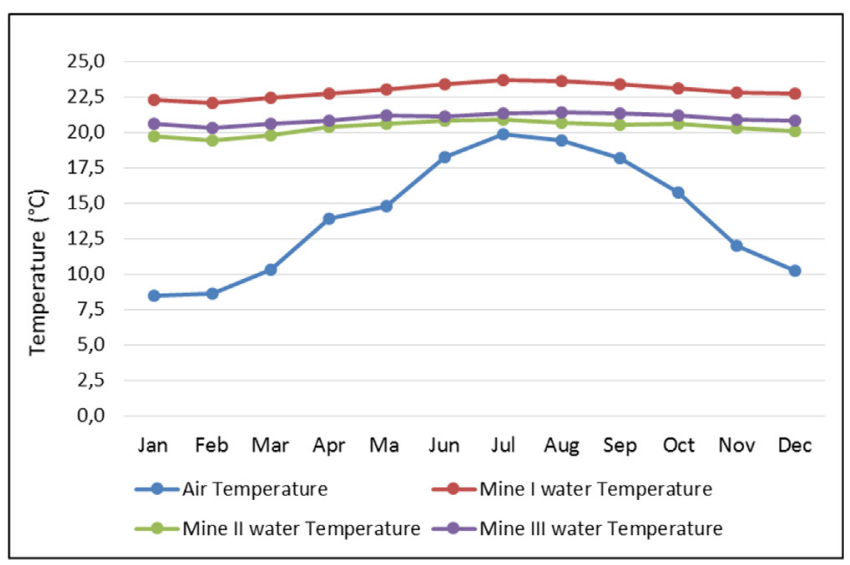

Fig. 2. Mine waters temperature for Mine I, Mine II and Mine III, and air temperature (monthly averages). temperatures are higher than ambient temperatures during the winter, when the heating of buildings is more demanding. Note that the temperature difference indicated in Fig. 2 represents an improvement in thermodynamic efficiency for heating compared with other air-sourced systems. The mine water temperature data has been provided by Hunosa mining company, and the air temperature data has been obtained from a meteorological station located in the study area.

Fig. 3 shows the scheme of a closed coal mine. When the extractive activity ceases, the flooding of the mining voids begins and a large underground water reservoir is formed. To avoid flooding problems in nearby areas, submersible pumps systems are required in order to maintain a water safety level, typically between 60 and $80 \mathrm{~m}$ below the ground level. Fig. 3 also shows the temperature gradient of the stored mine water in the three closed mines under study. Hunosa mining company provided the temperature profiles.

\subsection{Research statement}

The use of mine water is a low-carbon alternative that could create new economic activities in affected mining areas. The feasibility of using mine water for space heating and cooling of buildings depends mainly on the following characteristics:

- Distance from closed mine to potential users.

- Thermal energy demand and installed power.

- Temperature of the mine water.

- Discharge of mine water.

- Seasonal evolution of the mine water temperature.

- Hydrochemical composition of mine water.

\subsection{Thermal energy reserve}

The conventional way to estimate the geothermal energy reserved in the underground reservoir after the mine closure is based on the volume method [33]. The thermal energy available in mine waters depends on the volume of mine water stored and the water temperature difference between entering and leaving the heat pump. The volume of the mine waters stored in the three connected mines $(\mathrm{V})$ has been estimated in $8.64 \times 10^{6} \mathrm{~m}^{3}$. Hence, the static energy storage associated to the mine water is given by the following equation: 


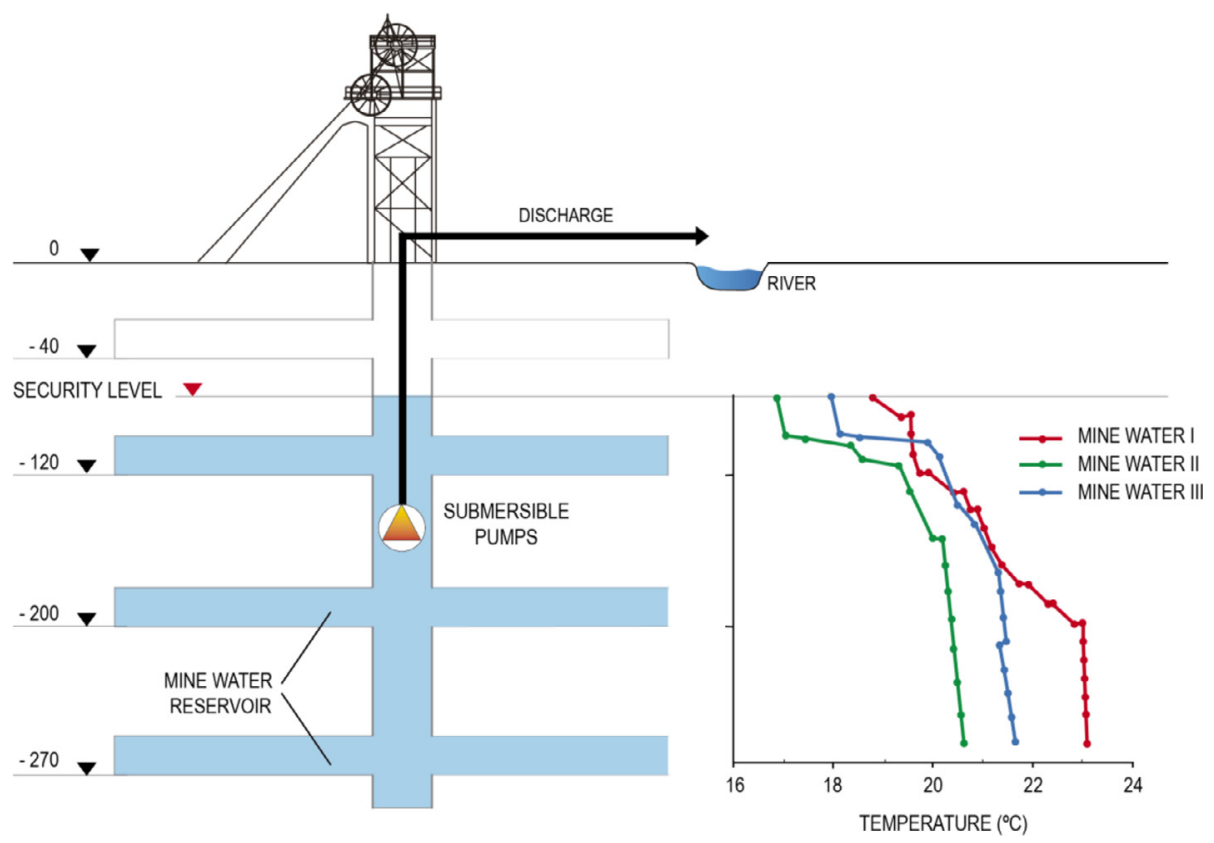

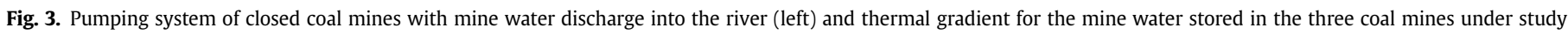
(right).

$E_{s}=\eta c \rho V\left(T_{h}-T_{c}\right)$

where $E_{s}$ is the static energy $(\mathrm{kWh}) ; \eta=2.7 \times 10^{-4}$ is the unit conversion factor $(\mathrm{kWh} / \mathrm{kJ})$; $\mathrm{c}$ is the specific heat of the mine water, assumed to be $4.18 \mathrm{~kJ} \mathrm{~kg}^{-1}\left({ }^{\circ} \mathrm{C}\right)^{-1} ; \mathrm{T}_{\mathrm{c}}$ is the mine water temperature after heat extraction via a tubular heat exchanger [34]; $T_{h}$ is the temperature of the mine water; and $\rho$ is the density of the mine water $\left(1,000 \mathrm{~kg} \mathrm{~m}^{-3}\right)$. Considering an average mine water temperature of $21.6^{\circ} \mathrm{C}$, and $5{ }^{\circ} \mathrm{C}$ drop in mine water temperature, a geothermal energy reserve of $5.0 \times 10^{7} \mathrm{kWh}$ is estimated by applying Eq. (1). Thermal energy available in mine waters is calculated based on $4-5{ }^{\circ} \mathrm{C}$ drop in mine water temperature, which is comparable to Banks et al. (2009) [35]. Since the output power of the geothermal plant depends on the available mine water flow rate, and considering 1,700 hear $^{-1}$ for heating and 800 hear $^{-1}$ for cooling [36], results in a water flow rate of $2,808 \mathrm{~m}^{3} \mathrm{~h}^{-1}$, and a thermal power of $20 \mathrm{MW}$ is finally obtained by applying Eq. (1). Table 3 shows the static thermal energy reserve and the thermal power for the three flooded mines considering the discharge indicated in Table 2. Table 3 also shows a comparison between static energy reserve in mine waters and the heat content in conventional fossil fuels (natural gas: $11.70 \mathrm{kWh} \mathrm{m}^{-3}$ and coal: $7 \mathrm{kWh}$ $\mathrm{kg}^{-1}$ ). Such geothermal energy stored in the three flooded mines is comparable to the heat content from $4.29 \times 10^{6} \mathrm{~m}^{3}$ of natural gas, or $7 \times 10^{4} \mathrm{t}$ of coal.

\subsection{Mine water heat recovery schemes}

The usual method to produce thermal energy from the mine water is based on the employment of subcritical cycles heat pumps in conjunction with open or closed geothermal loops [31,37-39]. Basically, the design of the geothermal loop systems to be introduced depends on the quality of the mine water (suspended solids, $\mathrm{pH}$ or hardness). In the case of low-quality mine water, it is recommended to install the heat exchanger inside the underground reservoir in a closed loop system. Once the thermal exchange has been carried out, the clean water circuit enters the heat pump to transfer the thermal energy. Complementarily, if the quality of the mine water is acceptable, it is preferable to install an open loop system. In the primary circuit, the mine water passes through a tubular heat exchanger and is discharged into a river (open loop). The secondary circuit provides a flow rate of clean water that passes through the tubular heat exchanger, recirculation to the heat pump (closed loop). Fig. 4 shows a mixed open loop and closed loop system scheme.

Heat pumps function using working fluids that undergo a phase change at the temperatures and pressures used in the heat pump system. Synthetic refrigerants such as chlorofluorocarbons, and hydrofluorocarbons have been used due to their high COP in heating and cooling systems [40]. However, environmental concerns over using this refrigerants have urged to investigate alternatives that can be used as an effective working fluids in heat

Table 3

Estimation of the static thermal energy in the flooded coal mines in NW Spain and heat conversion to fossil fuels.

\begin{tabular}{|c|c|c|c|c|}
\hline Parameter & Units & Mine I & Mine II & Mine III \\
\hline Temperature difference $\left(T_{h}-T_{c}\right)$ & ${ }^{\circ} \mathrm{C}$ & 5 & 5 & 5 \\
\hline Estimated voids volume & $\left(\mathrm{x} 10^{6}\right) \mathrm{m}^{3}$ & 2.48 & 3.28 & 2.88 \\
\hline Energy & $\mathrm{kWh}$ & $1.44 \times 10^{7}$ & $1.90 \times 10^{7}$ & $1.68 \times 10^{7}$ \\
\hline Discharge & $\mathrm{m}^{3} \mathrm{~h}^{-1}$ & 484,00 & $1.168,00$ & $1.156,00$ \\
\hline Output power & MW & 5.7 & 7.6 & 6.7 \\
\hline \multirow[t]{2}{*}{ Heat conversion to fossil fuels } & Natural gas $\left(\mathrm{m}^{3}\right)$ & $1.23 \times 10^{6}$ & $1.63 \times 10^{6}$ & $1.43 \times 10^{6}$ \\
\hline & $\operatorname{Coal}(\mathrm{t})$ & $2.0 \times 10^{4}$ & $2.7 \times 10^{4}$ & $2.3 \times 10^{4}$ \\
\hline
\end{tabular}




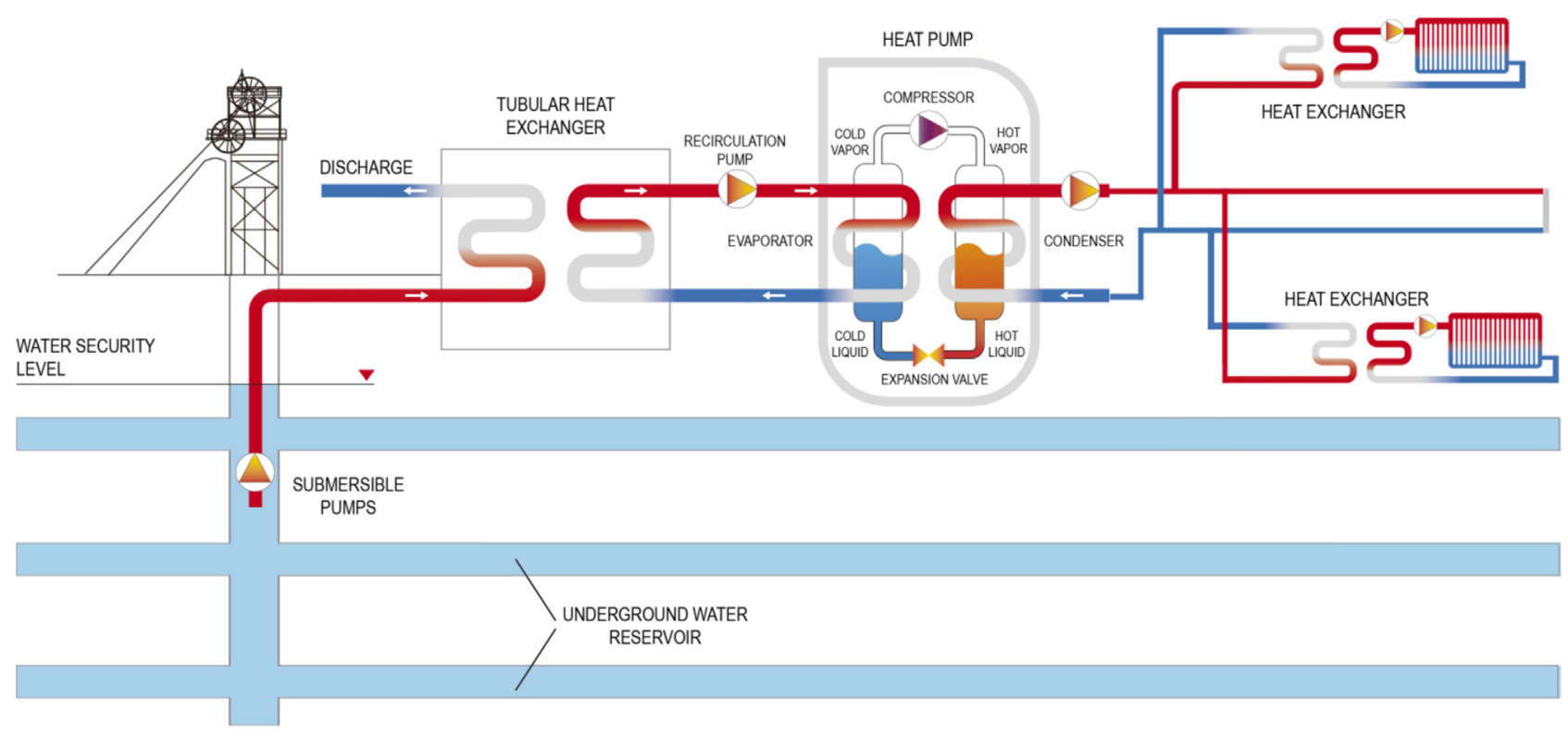

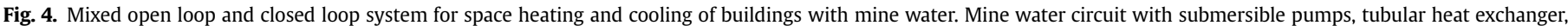
closed loop secondary circuit with clean water and heat pump components.

pumps. Thus, carbon dioxide $\left(\mathrm{R} 744 / \mathrm{CO}_{2}\right)$ has been investigated as natural refrigerant to use in heat pumps. However, the main concern of R744 plants has been the COP compared to conventional subcritical cycles. To improve the efficiency, different designs of heat exchangers, expansion devices and compressors have been developed to suit the $\mathrm{CO}_{2}$ transcritical cycle [40]. The transcritical cycle is thermodynamically different compared to a conventional vapor compression or refrigeration cycle. The pressure difference between heat absorption and heat rejection is much higher in a transcritical cycle, which results in significant thermodynamic losses in the expansion stage. R744 plants require components modifications. In a transcritical R744 heat pumps, the heat rejection takes place at the supercritical temperature and pressure. Regarding the gas cooler, a slit fin has higher heat transfer coefficient than a continuous fin for both the air-side and refrigerantside, which improves heat rejection. The R744 plants evaporator operates like conventional subcritical heat pump evaporators except that it experiences a much higher pressure (2-7 MPa) in the subcritical region [40]. A R744 heat pump operates at a much higher compressor discharge pressure (90-130 bar) compared to subcritical heat pumps (10-40 bar). Different compression mechanisms such as reciprocating, rotary, and scroll have been studied in order to improve the COP of the system. Some studies have verified that single-stage compression is less efficient than the two-stage system. An internal heat exchanger has been analyzed to ensure efficient operation of the compression stage.

Fig. 4 shows a diagram of a subcritical cycle heat pump system. In terms of heat pump design, the characteristics of the working fluid in operation can be defined first, so the geometry of the components are derived accordingly (on-design). On the contrary, an off-design is a model in which the components and boundary conditions are specified as an input, resulting in the state of the working fluid. In heating mode, the cold liquid refrigerant in heated by the clean water circuit in an evaporator (heat exchanger), where it is converted into a cold vapor. After the vaporization, it is then compressed (requiring an input of electrical energy), and converted into hot vapor and sent to a condenser (another heat exchanger). Here the hot vapor gives up the heat that was gained from the source in the evaporator and in the process is condensed to a hot liquid. The heat given up is what is used to space heating to buildings. Finally, the hot liquid goes through an expansion valve where the drop in pressure converts it to a cold liquid so the process can be repeated. In cooling mode the process in reversed using a reversing valve. In Fig. 4 the scheme considered after the heat pump for the thermal energy supply can also be observed. The return of the cold water from the heating circuits is heated in the heat exchanger of the heat pump (condenser), where hot vapor circulates. The hot water is sent back to the circuits by a circulation pump in a closed loop system. Note that, in cooling mode (summer), the water would be cooled in the heat pump.

Based on the results of the chemical analysis of mine water, a mixed open loop and closed loop system design has been considered. The submersible pumps boost the mine water to the tubular heat exchanger. The mine water transfers its energy into the heat exchanger located near the flooded mine. The recirculation pumps lead the clean water in a closed loop system to the heat pump located in the center of the thermal energy consumption. Modifying the temperature in the heat pump, the clean water returns to the main exchanger to repeat the process. The amount of heat generated divided by the amount of energy needed to operate the heat pump is known as the Coefficient of Performance (COP). Efficiency or COP of the heat pump is calculated using Eq. (2):

$$
C O P_{H P}=\frac{Q_{H P}}{W_{H P e}}
$$

where $\mathrm{W}_{\mathrm{HPe}}$ is the electrical consumption of heat pump in $\mathrm{kWh}$, and $\mathrm{Q}_{H \mathrm{H}}$ is the thermal energy output produced by the heat pump in $\mathrm{kWh}_{\mathrm{t}}$. The COP of the system includes the energy consumed by the heat pump, by the submersible pumps in closed mine and by circulation pumps, so it is calculated using Eq. (3).

$C O P_{\text {system }}=\frac{Q_{H P}}{W_{H P e}+W_{C P e}+W_{S P e}}$

where $W_{\mathrm{CPe}}$ is the electrical energy consumed by the circulation pumps in $\mathrm{kWh}$ and $\mathrm{W}_{\mathrm{SPe}}$ is the electrical energy consumed by the submersible pumps in $\mathrm{kWh}$. The major part of the electrical energy 
consumption in the heat pump is the compressor, which converts cold vapor into hot vapor. However, depending on the distance to the potential users, the circulation pumps (Fig. 4) could also consume a significant amount of electrical energy. For example, heat pumps with an output power of $5,000 \mathrm{~kW}$ require an electrical energy of $110 \mathrm{kWh}$ to supply the clean water at a distance of $2,000 \mathrm{~m}$

The electricity consumption of the heat pump will depend on the efficiency which in return it is based on the input and output level of temperatures of the water entering and leaving the heat pump [41]. In the case of an underfloor heating system (which has been considered for the present study), warm water is required at a temperature between 35 and $45^{\circ} \mathrm{C}$ to provide thermal energy to the radiant floor of buildings when operating in the heating mode.

\subsection{Geothermal plants design}

Table 4 shows the main characteristics of the geothermal plants using mine water in a mixed open loop and closed loop system for $1,3.5,5$ and $10 \mathrm{MW}$ of output power in the three mines under study. The heat pumps were to be installed in the center of the thermal energy consumption. Table 4 also shows the number of residential customers that can be satisfied with this approach, considering $10,000 \mathrm{kWh}$ year $^{-1}$ for heating consumption [34]. An average mine water temperature of $21.6^{\circ} \mathrm{C}$ has been applied in the three connected mines under study.

Investment cost rate, in $€ \mathrm{~kW}^{-1}$ and the energy consumed by the circulation pumps $\left(\mathrm{W}_{\mathrm{CPe}}\right)$, in $\mathrm{kWh}$, depends on the distance to potential users. It must be noted that the energy consumed by the submersible pumps (estimated at a depth of $60 \mathrm{~m}$ ) is a mandatory cost to be executed since it is necessary to maintain a safe flood level and avoid unwanted effects on the surface due to the groundwater rebound. Whatever the case, the analysis has been carried out from both different points of view, as shown in Fig. 5. On the one hand, considering the total consumption of electrical energy, which comprises heat pumps, submersible pumps and recirculation pumps, and leads to a lower COP of the system (Fig. 5 left). And on the other hand, taking into account the electrical consumption of heat pumps and circulation pumps only, which leads to a higher $\mathrm{COP}$ of the system (Fig. 5 right). Due to the required water temperatures $\left(35-45^{\circ} \mathrm{C}\right.$ in heating and $15-18{ }^{\circ} \mathrm{C}$ in cooling), the COP of the heat pump is increased.

Fig. 6 shows the scheme of heat exchange and water temperatures in heating and cooling considering the three flooded mines under study. Mixed open loop (primary circuit) and clean water closed loop (secondary circuit) can be observed in Fig. 6. The water flow rate for each output power has been indicated previously in Table 4 . The main elements of a geothermal plant are indicated in the scheme.

\section{Results and discussion}

\subsection{Energy balance and investment costs}

The annual energy between space heating and cooling of buildings using mine water and the electrical consumption of the system, in MWh year ${ }^{-1}$ is indicated in Fig. 7. Seasonal ambient temperature in the study area has been considered (Fig. 2), and 1,700 hyear $^{-1}$ for heating and 800 hear $^{-1}$ for cooling demand were estimated [36].

The investment cost depends on the distance from the flooded coal mines to the potential users. If the distance increases, civil works (excavation, installation of water pipeline and hydraulic accessories) are most expensive and larger circulation pumps are also needed to supply the water to the heat pumps located at the consumption center. Fig. 8 shows the investment costs, in $k €$, for geothermal energy plants of 1, 3.5, 5 and $10 \mathrm{MW}$ of output power, in the case of typical distances to potential users between 0.25 and $2 \mathrm{~km}$. For a distance of $250 \mathrm{~m}$, the investment cost is reduced by $30-40 \%$ (10 MW - 1 MW) compared to a distance of $2 \mathrm{~km}$.

\subsection{Economic feasibility of geothermal plants using mine water}

In this section, the economic feasibility of using mine water from closed coal mines for heating and cooling of buildings using a mixed open loop and closed loop is analyzed. Underfloor heating systems have been considered in the model. In heating mode, the required temperature of the water is around $35-45^{\circ} \mathrm{C}$, depending on the heat losses from the building. In cooling mode the water flow temperature will vary between 15 and $18^{\circ} \mathrm{C}$. Considering the thermal energy balance (Fig. 7) and the investment cost (Fig. 8), a profitability analysis has been carried out for geothermal plants of $1,3.5,5$ y $10 \mathrm{MW}$ of power. An economic model considering 25 years of operation phase has been developed.

\subsubsection{Parameters of the economic model}

The parameters of the economic model are given in Table 5. A thermal energy price of $45 € \mathrm{MWh}^{-1}$ and an electricity cost of 120 $€ \mathrm{MWh}^{-1}$ have been considered in the study [42]. The useful life of the geothermal energy plants is fixed to 25 years. The economic model parameters has been estimated according to the experience in the design and operation of mine water geothermal plants. The operation and maintenance (O\&M) costs are indicated depending on the power $\mathrm{P}$, in MW, according to classic correlations found in the open literature. O\&M costs also include overall costs for the different systems components.

\subsubsection{Profitability analysis}

From the data indicated in Table 5 , the profitability of the investments has been analyzed. Different scenarios of distance to the

Table 4

Main parameters of the geothermal energy plants using mine water for 1, 3.5, 5 and $10 \mathrm{MW}$ of output power.

\begin{tabular}{|c|c|c|c|c|}
\hline Geothermal plants design & $1 \mathrm{MW}$ & 3.5 MW & $5 \mathrm{MW}$ & $10 \mathrm{MW}$ \\
\hline Water flow rate $\left(\mathrm{m}^{3} \mathrm{~h}^{-1}\right)$ & 170 & 600 & 850 & 1,700 \\
\hline Energy supply (MWh year ${ }^{-1}$ ) & 2,498 & 8,693 & 12,840 & 24,930 \\
\hline Circulation pumps (kWh) & $15 d$ & $37 d$ & $55 d$ & $120 d$ \\
\hline Submersible pumps (kWh) & 52 & 170 & 255 & 520 \\
\hline Heat exchanger surface $\left(\mathrm{m}^{2}\right)$ & 152 & 498 & 716 & 1,385 \\
\hline Inside water pipes diameter (mm) & $2 \times 250$ & $2 \times 400$ & $2 \times 500$ & $2 \times 700$ \\
\hline Water velocity $\left(\mathrm{m} \mathrm{s}^{-1}\right)$ & 1.0 & 1.3 & 1.2 & 1.2 \\
\hline Investment cost rate $\left(€ \mathrm{~kW}^{-1}\right)$ & $270.89 d+587.81$ & $374 d+1,060.5$ & $442.2 d+1,417.7$ & $577.13 d+2,084.8$ \\
\hline Residential customers (household) & 170 & 595 & 850 & 1,700 \\
\hline
\end{tabular}

$\mathrm{d}=$ distance to potential users, in $\mathrm{km}$. 

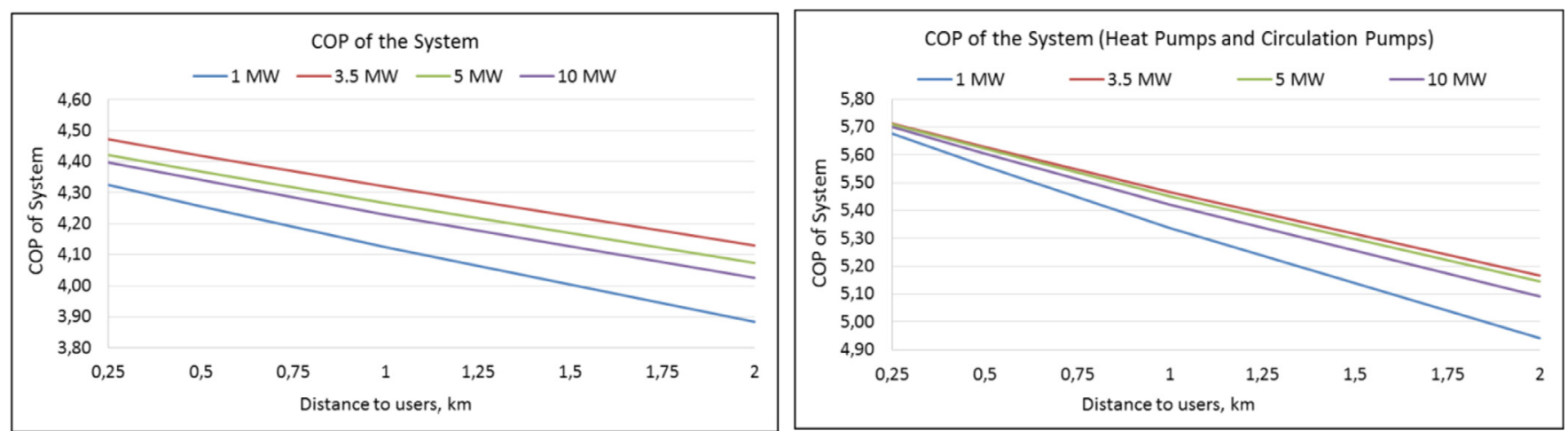

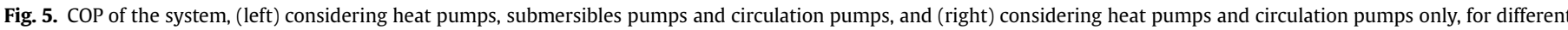
power values.

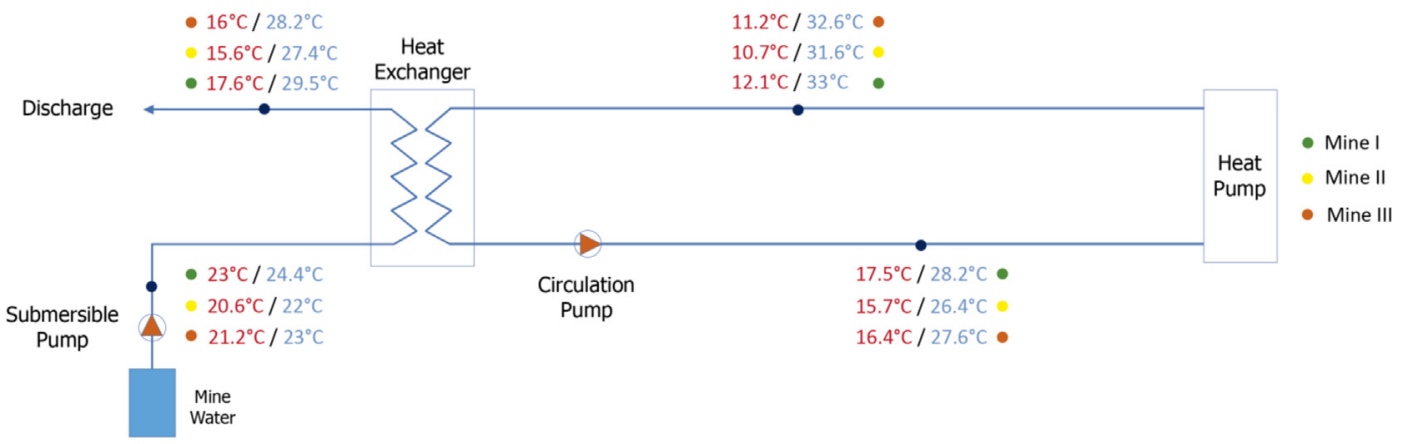

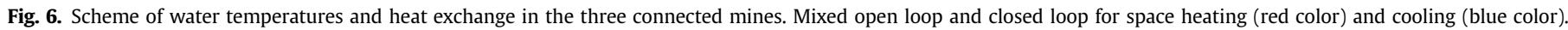

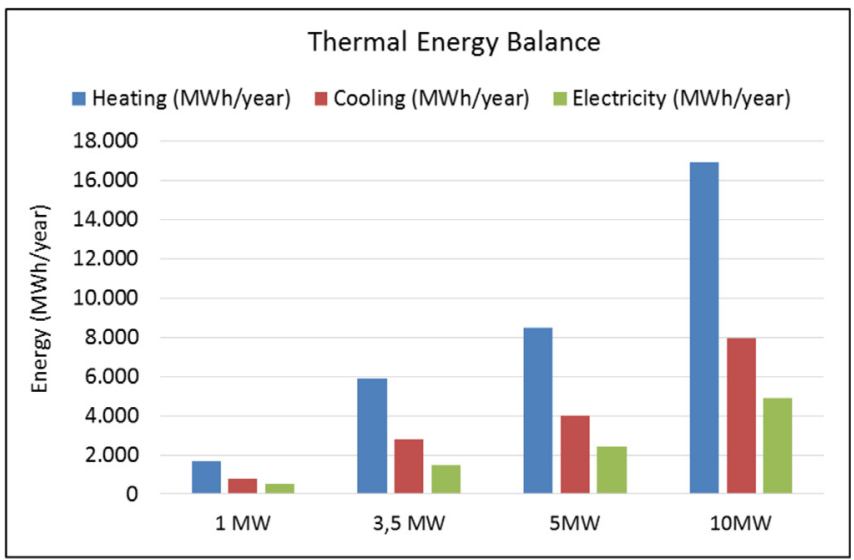

Fig. 7. Energy balance [MWh year $\left.{ }^{-1}\right]$. Heating and cooling production and electrical consumption for $1,3.5,5$ and $10 \mathrm{MW}$ of power.

potential users and overall COP have been considered for geothermal plants of $1,3.5,5$ and $10 \mathrm{MW}$ of power. When the distance to the potential users increases, the investment cost and the consumption of electrical energy to provide the water to the heat pumps increase, decreasing the COP of the system. In addition, the COP of the system also decreases when the depth of water level in the mine shaft increases. When the water level is deep, submersibles pumps will consume higher amount of energy to transport the mine water to the ground level. The O\&M cost includes electrical energy, as well as preventive and corrective maintenance.

Due to the water level in the flooded coal mine, the overall COP is expected to reach a value between 3.9 and 4.13 at a depth of $60 \mathrm{~m}$

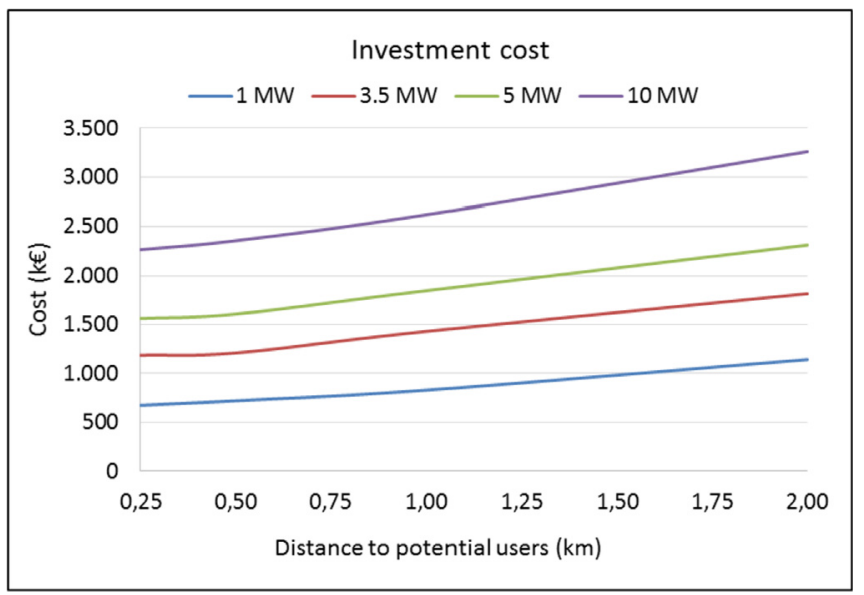

Fig. 8. Investment cost for geothermal energy plants of 1, 3.5, 5 and $10 \mathrm{MW}$ of output power depending on the distance (in $\mathrm{km}$ ) to potential users.

and at a distance to potential users of $2 \mathrm{~km}$. As indicated in section 3.5 , the energy consumed by the submersible pumps located in mine shaft is a mandatory cost to be executed since it is necessary to maintain a safe flood level. An overall COP between 4.94 and 5.1 at a distance of $2 \mathrm{~km}$ is obtained if the energy consumption of the submersible pumps is not consumed. Moreover, a suitable sizing of the water pipes must be carried out to minimize the load losses in the layout, reducing the power of circulations pumps and the electrical consumption. To determine the profitability of investments, the Net Present Value (NPV) and the Internal Rate of Return (IRR) have been calculated in the economic model for $1,3.5$, 
Table 5

Parameters of the economic model.

\begin{tabular}{lc}
\hline \multicolumn{2}{c}{ Economic model parameters } \\
\hline Thermal energy price $\left(€ \mathrm{kWh}^{-1}\right)$ & 0.045 \\
Electricity cost $\left(€ \mathrm{kWh}^{-1}\right)$ & 0.120 \\
O\&M cost $\left(€ \mathrm{year}^{-1}\right)$ & $65,792 \mathrm{P}+6,334.3$ \\
Useful life (years) & 25 \\
Equity (\%) & $20 \%$ \\
Debt (\%) & $80 \%$ \\
Loan interest rate $(\%)$ & $3.0 \%$ \\
Loan term (years) & 15 \\
Depreciation (years) & 25 \\
Return rate, NPV $(\%)$ & $4.5 \%$ \\
Annual CPI rate (\%) & $2.0 \%$ \\
\hline
\end{tabular}

5 and $10 \mathrm{MW}$ of output power at a distance to the buildings between 0.25 and $2 \mathrm{~km}$. Efficiencies of the system between 4 and 5.5 have been selected as indicated in Fig. 5 . The parameters summarized in Table 5 and the amounts of thermal energy given in Fig. 7 have also been considered in the economic model.

In general, the NPV and the IRR decrease when the distance increases and the overall COP decreases. The NPV and the IRR also decrease when the installed thermal power decreases. Fig. 9 shows the results of the NPV $(k €)$ for the scenarios that have been indicated. The highest NPVs are reached in the installation of $10 \mathrm{MW}$ of output power with an overall COP of 5.5 and a distance to potential users of $0.25 \mathrm{~km}$, obtaining a NPV of $4,409.85 \mathrm{k} €$. For a geothermal plant with $10 \mathrm{MW}$ of power and a distance of $0.25 \mathrm{~km}$, if the energy consumption of the submersible pumps installed in the mine shaft is considered, the COP of the system is reduced to 4.36 and the value of NPV decreases to $2,630 \mathrm{k} €$. If the distance to potential user

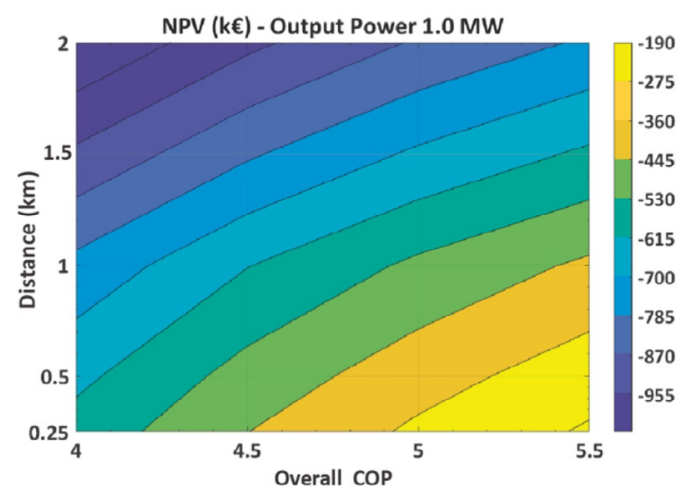

a)

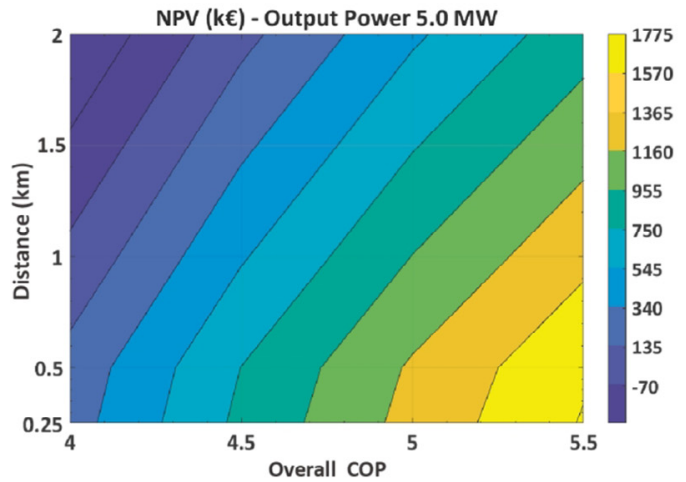

c) increases to $2 \mathrm{~km}$, the overall COP decreases to 4.03 and the NPV decreases to $798.37 \mathrm{k} €$.

In a geothermal plant of $5 \mathrm{MW}$ of power and a distance of $2 \mathrm{~km}$, the NPV reached $716.15 \mathrm{k} €$, considering an overall COP of 5.14. When the energy consumption of the submersible pumps is considered, the COP decreases to 4.07 and the NPV is reduced to $-263.20 \mathrm{k} €$. For geothermal plants of $3.5 \mathrm{MW}$ of power at a distance of $2 \mathrm{~km}$ with an overall COP 5.17, the NPV reached 253.98 $\mathrm{k} \in$. If the consumption of the mine pumps is considered in the energy balance, the COP decreases to 4.13 and the NPV obtained is $-343.35 \mathrm{k} €$. Finally, for geothermal plants of $1 \mathrm{MW}$ of installed power, due to the low thermal energy consumption, NPV negative is obtained in all scenarios that have been analyzed.

Fig. 10 shows the results of the IRR (\%) for the scenarios that have been indicated. The maximum IRR obtained is $17.76 \%$, for an installation with $10 \mathrm{MW}$ of power and $0.25 \mathrm{~km}$ of energy supply distance, with an overall COP of 5.5. For a plant with $1 \mathrm{MW}$ of installed power, the highest IRR that has been obtained is $2.95 \%$.

To determine profitability, a minimum IRR of $8 \%$ has been selected. In Fig. 10, the areas with an IRR greater than $8 \%$, are indicated, separated with dashed lines (Zone A). In geothermal plants of $1 \mathrm{MW}$ the IRR established in any scenario is not reached. Areas with an IRR greater than $8 \%$ increase when the installed power increases. For a $3.5 \mathrm{MW}$ power plant, the project is profitable when the overall COP is higher than 4.47 and the distance is less than $1.5 \mathrm{~km}$. For a thermal plant with $5 \mathrm{MW}$ of power, the expected profitability for COP lower than 4.22 is not achieved. For COP of the system greater than 4.22 the profitability depends on the distance. For a COP of the system of 5 , the maximum distance would be $1.5 \mathrm{~km}$, and for an overall COP of 4.5 the maximum distance would be $1 \mathrm{~km}$. A geothermal plant of $10 \mathrm{MW}$ of power reaches IRR greater

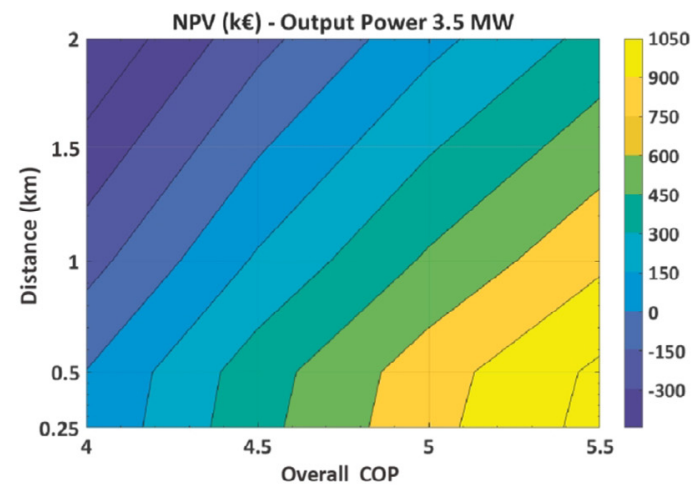

b)

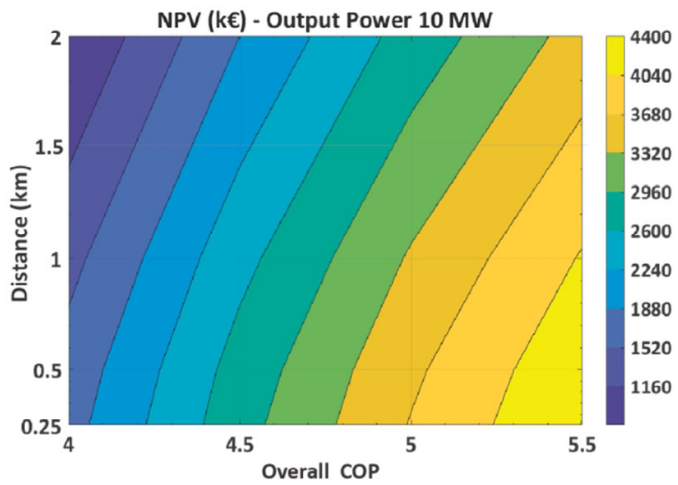

d)

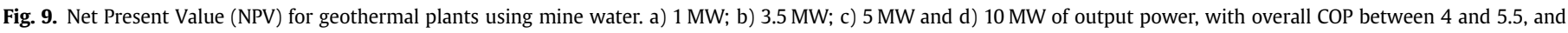
distances to potential users between 0.25 and $2 \mathrm{~km}$. 


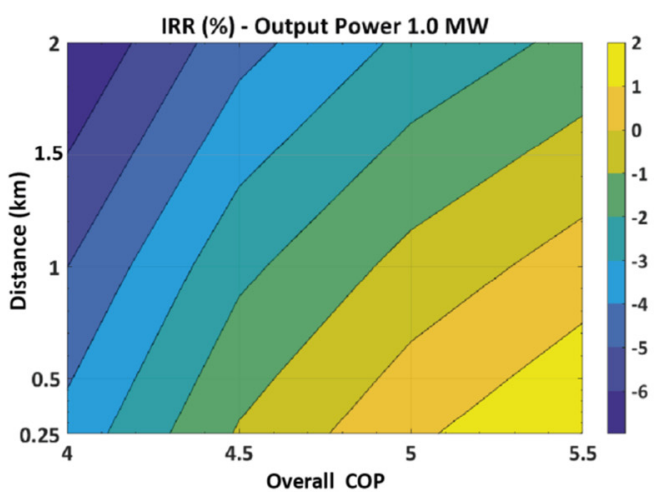

a)

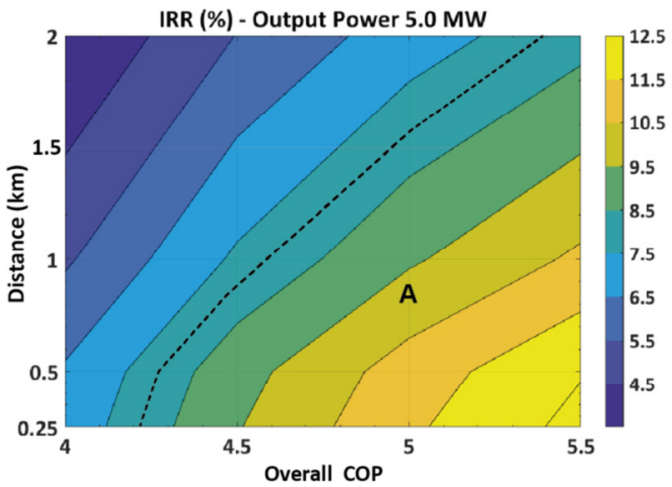

c)

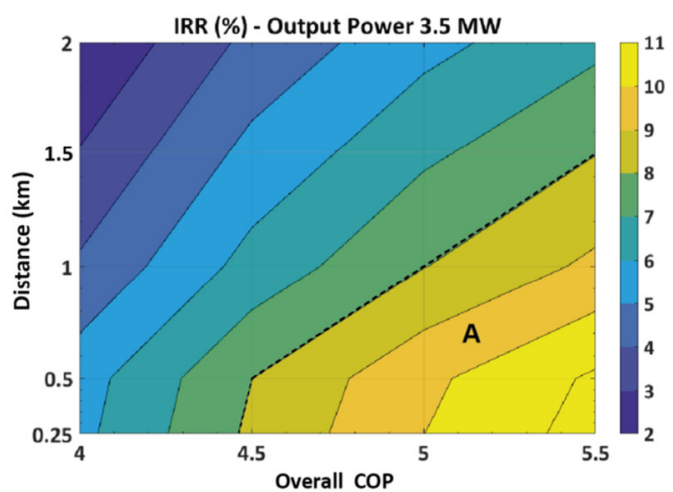

b)

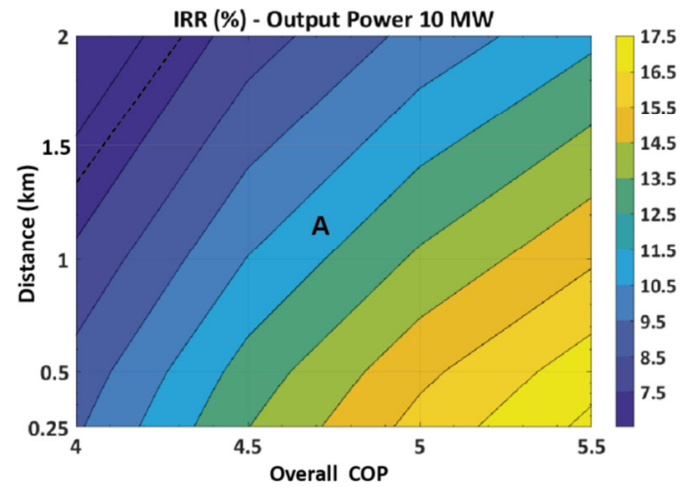

d)

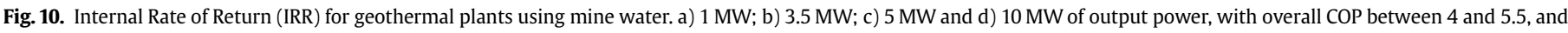
distances to potential users between 0.25 and $2 \mathrm{~km}$.

than $8 \%$ in all scenarios of overall COP that have been analyzed. However, for a distance to potential users of $2 \mathrm{~km}$, an overall COP of 4.36 is necessary to obtain an IRR of $8 \%$. As indicated in Fig. 5, the overall COP of a geothermal plant with $3.5 \mathrm{MW}$ of power is 5.52 for a distance of $0.85 \mathrm{~km}$. For a plant with $5 \mathrm{MW}$ of power, the overall COP is 5.30 for a distance of $1.5 \mathrm{~km}$ and 5.46 for a distance of $1 \mathrm{~km}$. For geothermal plants with $10 \mathrm{MW}$ of power, the COP of the system is 5.09 for a distance to potential users of $2 \mathrm{~km}$.

In summary, it has been observed that the highest profitability is obtained for a high demand of thermal energy and for short distances to potential users. For the three connected mines under study, a geothermal plants with $1 \mathrm{MW}$ of power are not economically feasible, 3.5 MW geothermal plants are feasible for distances lower than $1.5 \mathrm{~km}, 5 \mathrm{MW}$ plants reach the expected profitability for distances close to $2 \mathrm{~km}$, and finally, $10 \mathrm{MW}$ geothermal plants reach a profitability of $12 \%$ for a distance to potential users of $2 \mathrm{~km}$.

\subsection{Reduction of carbon emissions}

The use of mine water for the generation of thermal energy supposes a reduction of carbon emissions. Heat pumps for space heating and cooling to buildings require electrical energy to operate, mainly in the compressor to produce hot vapor which is used in the condenser to transfer thermal energy to the buildings. In 2018, grid-connected electricity generation in Spain comprised of coal fired $(14.3 \%)$, nuclear $(20.3 \%)$ and natural gas (11.5\%), in addition to RES (51.6\%), with others fuels occupying the remaining $2.3 \%$ [43]. The increase in renewable electric generation has reduced the $\mathrm{CO}_{2}$ emission factor to $0.246 \mathrm{kgCO}_{2} \mathrm{kWh}^{-1}$ in 2018 [43]. Natural gas heating systems emit less $\mathrm{CO}_{2}$ per kWh than electrical energy, and therefore have lower $\mathrm{CO}_{2}$ emission factor; $0.204 \mathrm{kgCO}_{2} \mathrm{kWh}^{-1}$ Table 6 shows the carbon emissions in $\mathrm{tCO}_{2}$ year $^{-1}$ for conventional fossils fuel compared to mine water geothermal energy to produce thermal energy. An average efficiency of the system (COP) of 5.1 has been considered. Very significant reductions in the $\mathrm{CO}_{2}$ emissions are obtained using mine water, more than $76 \%$ compared to natural gas, electrical energy and diesel oil. The increase in the share of renewable energies in the electricity mix would imply an even greater difference compared to natural gas or diesel oil.

\subsection{Drawbacks and uncertainties}

As indicated in the previous section 4.3 , the use of mine water for heating and cooling of buildings has important environmental benefits. These initiatives also aid to ensure economic development of depressed mining areas after closure. However, compared to conventional systems, there are several drawbacks pertaining to:

- Higher investment and O\&M costs: Natural gas condensing boilers have an investment cost of about $120 € \mathrm{~kW}^{-1}$, much lower than geothermal plants. The investment cost of a

Table 6

Carbon emissions: geothermal energy using mine water compared to conventional fossil fuels $\left[\mathrm{tCO}_{2}\right.$ year $\left.^{-1}\right]$.

\begin{tabular}{lllll}
\hline Carbon emissions $\left[\mathrm{tCO}_{2}\right.$ year $\left.^{-1}\right]$ & $1 \mathrm{MW}$ & $3.5 \mathrm{MW}$ & $5 \mathrm{MW}$ & $10 \mathrm{MW}$ \\
\hline Natural Gas & 549.8 & $1,526.9$ & $2,619.4$ & $5,085.7$ \\
Electrical energy & 663.0 & $1,841.3$ & $3,158.6$ & $6,132.8$ \\
Diesel oil & 773.5 & $2,148.2$ & $3,685.1$ & $7,154.9$ \\
Mine water geothermal energy & 130.0 & 361.0 & 619.4 & $1,202.5$ \\
\hline
\end{tabular}


geothermal plant of $1 \mathrm{MW}_{\mathrm{t}}$ of output power reaches $850 € \mathrm{~kW}^{-1}$ considering a distance to potential users of $1 \mathrm{~km}$. Natural gas or electrical boilers could be installed directly in the building, while geothermal plants require a pipeline network to transport the water from the flooded mine to the centers of energy consumption. The O\&M cost amounts to $5,000 € \mathrm{MW}^{-1}$ year $^{-1}$ in conventional systems, and increases to $21,500 € \mathrm{MW}^{-1}$ year ${ }^{-1}$ for geothermal systems.

- Security of energy supply: Systems that use natural gas boilers have slightly higher security of energy supply. Geothermal systems are more complex, because more equipment, such as, submersible pumps, heat exchanger, circulation pumps, and heat pumps, is required. Therefore, the possibility of problems or breakdowns in the equipment or pipeline network increases in geothermal plants. Normally, natural gas boilers are used as backup for geothermal systems.

- Geothermal systems are suitable for underfloor heating systems, where the temperature required is lower $\left(35-45^{\circ} \mathrm{C}\right.$ in heating mode and $15-18^{\circ} \mathrm{C}$ in cooling mode). In conventional hot water radiators, depending on the outside ambient conditions, the temperature required could reach $75^{\circ} \mathrm{C}$. In geothermal plants, the COP of the heat pump is remarkably reduced for high service temperatures.

In addition, there is likely to be a number of uncertainties that must be taken into account, such as, possible impacts of droughts, effects of climate change, changes in mine water chemical parameters, legal and administrative aspects and political factors [44]. Regarding the impacts of drought, the volume of available mine water and the geothermal potential could be reduced. The increase in global temperature will imply a reduction in the demand for heating systems.

\section{Conclusions}

Mine water from three closed coal mines, located in the ACCB (NW Spain) and is presented as an interesting option for local geothermal energy generation. The temperature of the stored mine water was found to be $20-23^{\circ} \mathrm{C}$, showing low seasonal variations, and the available volume of mine water in the three mines was calculated as $7 \times 10^{6} \mathrm{~m}^{3}$ year $^{-1}$. The results obtained show that $20 \mathrm{MW}$ of thermal energy is available for heat recovery from mine waters, compared to $4 \mathrm{MW}$ of electrical power committed for pumping from inside the mines and heat pump consumption.

A high efficiency heat pump with conventional subcritical cycle and a mixed open loop and closed loop configuration is proposed to produce geothermal energy for heating and cooling of buildings. Underfloor heating systems have been considered, where the water temperature required is $35-45^{\circ} \mathrm{C}$ in heating mode, and $15-18{ }^{\circ} \mathrm{C}$ in cooling mode. The economic feasibility depends, fundamentally, on the overall COP and the distance to potential users. The main parameters that impact the overall efficiency are: i) the input and output level of temperatures of the water entering and leaving the heat pump, ii) the depth of water in the mine shaft, and iii) the distance through which the clean water has to be transported by the circulation pumps to the heat pumps in the buildings. When the distance to potential users and/or the temperature required by the heating system are high, the overall COP decreases. In addition, when the distance increases, investment costs increase and profitability is affected. The energy consumed by the submersible pumps (located at the mine shafts) is not taken account in the energy balance, since it is an electric consumption that in any case must be executed.

The results of the economic model shown that a geothermal plant with $1 \mathrm{MW}$ of power does not reach the expected profitability
$($ IRR $=8 \%)$ in any of the scenarios that have been analyzed. Geothermal plants with $3.5 \mathrm{MW}$ of power reach the expected profitability with overall COP greater than 4.95 and distance to buildings less than $0.85 \mathrm{~km}$. Geothermal plants with $5 \mathrm{MW}$ of power are profitable with overall COP greater than 4.22 depending on the distance to potential users. A geothermal plant with $10 \mathrm{MW}$ of power reaches IRR greater than $8 \%$ in all scenarios of overall COP that have been considered.

The use of mine water as geothermal resource in closed and flooded underground coal mines has important economic and environmental benefits. The results obtained in the present work suggest that 5,952 $\mathrm{tCO}_{2}$ year $^{-1}$ are reduced in a geothermal plant of $10 \mathrm{MW}$ of power, compared to conventional fossil fuels. The $\mathrm{CO}_{2}$ emission factor of geothermal plants using mine water is 0.048 $\mathrm{kgCO}_{2} \mathrm{kWh}^{-1}$, much lower than natural gas $\left(0.204 \mathrm{kgCO}_{2} \mathrm{kWh}^{-1}\right)$ or electrical energy $\left(0.246 \mathrm{kgCO}_{2} \mathrm{kWh}^{-1}\right)$.

\section{Acknowledgements}

Authors thank the mining company HUNOSA for providing valuable information.

\section{References}

[1] European Commission. Eurostat. https://ec.europa.eu/eurostat.

[2] P.L. Younger, K.F. Bradley, Application of geochemical mineral exploration techniques to the cataloguing of problematic discharges from abandoned mines in North-East England, in: Proceedings of the $5^{\text {th }}$ International Mine Water Congress. Nottingham, 1994, pp. 857-871.

[3] W.G. Coldewey, L. Semrau, Mine water in the Ruhr area (Federal Republic of Germany), in: Proceedings of $5^{\text {th }}$ International Mine Water Congress, September, vol. 9, Leicestershire: Quorn Selective Repro Limited, 1994, p. 148

[4] S. Dumpleton, The dangerous legacy of dead collieries, Int. J. Rock Mech. Min. Sci. Geomech. Abstr. 1 (33) (1996) 41A.

[5] A. Ordóñez, S. Jardón, R. Álvarez, C. Andrés, F. Pendás, Hydrogeological definition and applicability of abandoned coal mines as water reservoirs, J. Environ. Monit. 14 (2012) 2127-2136, https://doi.org/10.1039/c2em11036a.

[6] C.J. Gandy, P.L. Younger, Predicting groundwater rebound in the south yorkshire coalfield, UK, Mine Water Environ. 26 (2007) 70-78, https://doi.org/ 10.1007/s10230-007-0153-7.

[7] P.L. Younger, The Longevity of minewater pollution: a basis for decisionmaking, Sci. Total Environ. 194/195 (1997) 457-466.

[8] P.A. García Fuente, Doctoral Thesis, Sistema experto de predicción de desagües en minas subterráneas de carbón. Aplicación al Grupo Aller de Hunosa, vol. 2, Universidad de Oviedo, Inédita, 1996.

[9] P. Younger, Possible environmental impact of the closure of two collieries in County Durham, Water Environ. J. 7 (5) (1993) 521-531.

[10] P. Younger, Coalfield abandonment: geochemical processes and hydrochemical products, Energy Environ. Geochem. Fossil. Nucl. Renew. Resour. Soc. Environ. Geochem. Health. MacGregor. Sci. (1998) 1-29 (Insch).

[11] M.P. Henton, The problem of water table rebound after mining activity and its effect on ground and surface water quality, Stud. Environ. Sci. 17 (1981) $111-116$.

[12] M.W. Stoertz, M.L. Hughes, N.S. Wanner, M.E. Farley, Long-term water quality trends at a sealed, partially flooded underground mine, Environ. Eng. Geosci. 7 (1) (2001) 51-65.

[13] S. Wood, P. Younger, N. Robins, Long-term changes in the quality of polluted minewater discharges from abandoned underground coal workings in Scotland, Q. J. Eng. Geol. Hydrogeol. 32 (1) (1999) 69-79.

[14] G.R. Watzlaf, T.E. Ackman, Underground mine water for heating and cooling using geothermal heat pump systems, Mine Water Environ. 25 (1) (2006) $1-14$.

[15] S. Kindaichi, D. Nishina, L. Wen, T. Kannaka, Potential for using water reservoirs as heat sources in heat pump systems, Appl. Therm. Eng. 76 (2015) $47-53$

[16] J. Raymond, R. Therrien, Low-temperature geothermal potential of the flooded Gaspé mines, Québec, Canada, Geothermics 37 (2) (2008) 189-210.

[17] E.P. Ramos, K. Breede, G. Falcone, Geothermal heat recovery from abandoned mines: a systematic review of projects implemented worldwide and a methodology for screening new projects, Environ. Earth Sci. 73 (11) (2015) 6783-6795.

[18] J. Menendez, J. Loredo, J. Fernandez-Oro, M. Galdo, Energy storage in underground coal mines in NW Spain: assessment of an underground lower water reservoir and preliminary energy balance, Renew. Energy 134 (2019) 1381-1391. https://doi.org/10.1016/j.renene.2018.09.042.

[19] J. Menendez, J.M. Fernandez-Oro, M. Galdo, J. Loredo, Pumped-storage hydropower plants with underground reservoir: Influence of air pressure on the 
efficiency of the Francis turbine and energy production, Renew. Energy 143 (2019) 1427-1438. https://doi.org/10.1016/j.renene.2019.05.099.

[20] S. Rehman, L. Al-Hadhrami, M. Alam, Pumped hydro energy storage system: a technological review, Renew. Sustain. Energy Rev. 44 (2015) 586-598. https://dx.doi.org/10.1016/j.rser.2014.12.040.

[21] F. Winde, F. Kaiser, E. Erasmus, Exploring the use of deep level gold mines in South Africa for underground pumped hydroelectric energy storage schemes, Renew. Sustain. Energy Rev. 78 (2016) 668-682. https://dx.doi.org/10.1016/j. rser.2017.04.116.

[22] A. Yucekaya, The operational economics of compressed air energy storage systems under uncertainty, Renew. Sustain. Energy Rev. 22 (2013) 298-305. https://doi.org/10.1016/j.rser.2013.01.047.

[23] G. Farr, S. Sadasivam, I.A. Watson, H.R. Thomas, D. Tucker, Low enthalpy heat recovery potential from coal mine discharges in the South Wales Coalfield, Int. J. Coal Geol. 164 (2016) 92-103.

[24] A. Jessop, Geothermal energy from old mines at Springhill, Nova Scotia, Canada, in: Proceedings World Geothermal Congress, 1995, pp. 463-468.

[25] Geothermal Mine Water as an Energy Source for Heat Pumps, Cadet Energy Efficiency, October 1992

[26] E. Roijen, P. Op't Veld, E. Demollin-Schneiders, in: The Minewater Project Heerlen-Low Exergy Heating and Cooling in Practice, PALENC AIVC, 2007.

[27] R. Matthes, J. Schreyer, Remediation of the Old Wismut-Shaft 302 in Marienberg and installation of a technical plant for geothermal mine water use, in: IMWA Symposium 2007: Water in Mining Environments, 2007.

[28] K. Kranz, J. Dillenhart, Mine water utilization for geothermal purposes in Freiberg, Germany: determination of hydrogeological and thermophysical rock parameters, Mine Water Environ. 29 (2010) 68-76.

[29] Municipal building, Park Hills, Missouri - Technical Report, Caneta research, 1997.

[30] G. Gzyl, D. Banks, P. Younger, M. Głodniok, N. Burnside, B. Garzon, A. Skalny, Low Carbon After-Life - overview and first results of project LoCAL, in: Proceedings International Mine Water Congress, vol 2016, IMWA, Freiberg/Germany, 2016.

[31] A. Hall, J.A. Scott, H. Shang, Geothermal energy recovery from underground mines, Renew. Sustain. Energy Rev. 15 (2011) 916-924. https://doi:10.1016/j. rser.2010.11.007.

[32] D. Banks, H. Skarphagen, R. Wiltshire, C. Jessop, Mine water as a resource: space heating and cooling via use of heat pumps, Land Contam. Reclam. 11 (2) (2003) 191-198.

[33] J. Raymond, R. Therrien, Low-temperature geothermal potential of the flooded Gaspé mines, Québec, Canada, Geothermics 37 (2008) 189-210.

[34] T. Bao, J. Meldrum, C. Green, S. Vitton, Z. Liu, K. Bird, Geothermal energy recovery from deep flooded copper mines for heating, Energy Convers. Manag. 183 (2019) 604-616. https://doi.org/10.1016/j.enconman.2019.01.007.

[35] D. Banks, A. Fraga Pumar, I. Watson, The operational performance of Scottish Minewater-based ground source heat pump systems, Q. J. Eng. Geol. Hydrogeol. 42 (3) (2009) 347-357.

[36] K. Ochsner, Geothermal Heat Pumps. A Guide to Planning and Installing, vo 2007, Earthscan, London, 2008, p. 167.

[37] M. Ghomshei, J.A. Meech, Usable heat from mine water: coproduction of energy and minerals, from "Mother Earth", in: MeechJA, Y. Kawazoe, KumarVJ J. Maguire, H.P. Wang (Eds.), Intelligence in a Materials World: Nanotechnology for the 21st Century, CRC Press, 2003, p. 5.

[38] L.F. Cabeza, A. Solé, C. Barreneche, Review on sorption materials and technologies for heat pumps and thermal energy storage, Renew. Energy 110 (2016) 3-39. https://doi.org/10.1016/j.renene.2016.09.059.

[39] R. Rodriguez, M.B. Díaz, Analysis of the utilization of mine galleries as geothermal heat exchangers by means a semi-empirical prediction method, Renew. Energy 7 (2009) 1716-1725. https://doi.org/10.1016/j.renene.2008 12.036.

[40] R. Uddin Rony, H. Yang, S. Krishnan, J. Song, Recent advances in transcritical CO2 (R744) heat pump system: a review, Energies 12 (2019) 457, https:// doi.org/10.3390/en12030457.

[41] A. Al-Habaibeh, A.P. Athresh, K. Parker, Performance analysis of using mine water from an abandoned coal mine for heating of buildings using an open loop based single shaft GSHP system, Appl. Energy 211 (2018) 293-402. https://doi.org/10.1016/j.apenergy.2017.11.025.

[42] Iberian Energy Market Operator, OMIE, 2019. www.omie.es. (Accessed 10 April 2018).

[43] Spanish Electrical Grid (REE). https://www.ree.es/es/estadisticas-del-sistemaelectrico-espanol/series-estadisticas/series-estadisticas-nacionales.

[44] J. Menendez, A. Ordóñez, R. Álvarez, J. Loredo, Energy from closed mines: underground energy storage and geothermal applications, Renew. Sustain. Energy Rev. 108 (2019) 498-512. https://doi.org/10.1016/j.rser.2019.04.007. 